\title{
EFFicient Heating ANd COOLING With Borehole Heat EXChangers
}

\author{
Axel Gerschel ${ }^{1}$; Markus Haack ${ }^{2}$; Prasanth Subramani; Lukas Stöckmann; Thomas \\ Schäfer; Tom Walter; Tino Schütte; Jörn Krimmling \\ Hochschule Zittau/Görlitz, University of Applied Sciences, \\ Fakultät Wirtschaftswissenschaften und Wirtschaftsingenieurwesen, \\ Theodor-Körner-Allee 16, 02763, Zittau, Germany \\ e-mail: ${ }^{1}$ axel.gerschel@hszg.de; ${ }^{2}$ m.haack@hszg.de
}

\begin{abstract}
Ground-source heat pumps are a sustainable technology to increase the use of renewable energy sources. In order to exploit the maximum potential of near-surface geothermal energy, optimization concepts for borehole heat exchanger systems that combine heating and cooling are being developed at the University of Applied Sciences Zittau/Görlitz. The objectives of this research are not only the reduction of primary energy consumption but also the development of predictive models for system planning, especially with respect to the influence of groundwater. Additionally, constructive and economic aspects of borehole heat exchanger systems are evaluated.
\end{abstract}

\section{Keywords}

Near-surface geothermal energy; Heat pump; Borehole heat exchanger; Renewable energy; Seasonal thermal energy storage; Groundwater flow.

\section{Introduction}

The use of near-surface geothermal energy for heating and cooling of buildings is an efficient alternative to conventional systems. Utilizing geological subsoil as a heat source and sink provides large potential for saving primary energy. By this, it helps to achieve ambitious energy transition targets [1]. Together with panel heating and cooling systems, geothermal probes are particularly suitable as underground heat exchangers. Ground-source heat pump (GSHP) systems can unfold their maximum performance capabilities by using subsoil as thermal storage and in case of combined heating and cooling applications. For this purpose further research on planning methods, prediction models and practical operational concepts are essential. Therefore, an interdisciplinary junior research group at Zittau/Görlitz University of Applied Sciences was established. This group consists of researchers specialized in the fields of applied mathematics, engineering, geosciences and economics.

\section{$1 \quad$ Optimization Issues of Geothermal Energy Systems}

The main topic of research deals with geothermal energy supply concepts for non-residential buildings. In addition to covering heating demand, the energy supply systems in these buildings more and more often have to cover construction and usage-related cooling demand. However, complex energy demand structures lead in planning practice often to uncertainties in the design of borehole heat exchanger (BHE) fields [2]. Therefore, the optimal utilization of natural regeneration and energy storage effects of the subsoil requires the development of new approaches in the constructive design of the BHE field and the BHE itself. Associated problems have to be investigated through parameter studies with the aid of high-resolution numerical building and system simulation models. The aim is to systematize the decision- 
making process for an optimal system configuration (building and its entire technical equipment) by model-based optimization and evaluation of multidimensional efficiency criteria. Additional aspects are the assessment of planning models with respect to their prediction accuracy and the evaluation of over as well as under dimensioning effects in the constructive design of BHEs.

\section{The Influence of Geology and Groundwater}

The heat transport and possible thermal storage in the subsoil varies considerably, depending on local geological and hydrogeological conditions. Hence, the influence of the prevailing geology and groundwater situation in association with the usage of near-surface geothermal energy is another key topic of this research project. Detailed knowledge of the thermal properties of the subsoil is essential for a profound design of BHE systems. In this context, the thermal conductivity and heat capacity of the rock layers as well as natural underground temperature belong to the most important properties that are highly location-dependent. Unfortunately, hydrogeological factors, especially convective heat transport induced by groundwater flow, are often neglected during system dimensioning. The reason for this is that currently no well-engineered application-oriented planning guide exists for this specific problem. In addition, generation of costly and time-consuming numerical groundwater flow models are often not justified in planning practice [3, 4]. However, especially when the geological subsoil is used as a seasonal thermal storage by combined heating and cooling applications, the groundwater flow induces convection that influences the system performance negatively. The ignorance of groundwater flow may lead to under dimensioning of BHE fields. Contrary to that, groundwater flow can increase the performance of solo heating applications. The utilization of the subsoil rock for thermal storage can increase the efficiency of ground-source heat pump systems. Therefore, considerations of hydrogeological factors in the development of planning and design tools are inevitable.

The above-mentioned questions are being answered within the framework of thermohydraulic modelling at Zittau/Görlitz University of Applied Sciences. The permeability coefficient $\left(\mathrm{k}_{\mathrm{f}}\right.$-value) and the effective porosity of relevant rock layers as well as the hydraulic gradient of groundwater belong to the hydraulic aquifer properties in the centre of attraction [3]. These hydrogeological parameters have to be systematized with respect to their influence on the heat transport and its consequences for the overall system dimensioning. Based on this, simplifications can be derived for perspective developments of new approaches in dimensioning of BHE fields.

\section{$3 \quad$ BHE Test Bench for Experimental Investigations}

In order to validate the model through experimental investigation a test bench equipped with extensive measurement technology is available (Fig. 1). The system consists of three BHEs of type PE-Xa $32 \mathrm{~mm}$ double-U with different depths arranged in triangular form. Heating operation can be realized by means of a built-in compression chiller. On the other hand, simulation of the cooling operation, as well as feeding of solar thermal energy, can be realized with the help of a gas-condensing boiler. All main components as well as integrated thermal buffer storage are connected to each other via a comprehensive hydraulic system (Fig. 2). All BHEs, including the control probe at the centre, have a full-length fieldbus sensor system to measure the temperature every meter in depth.

The system design allows operations of single or multiple BHEs with individually adjustable flow rates and defined heating or cooling power (heating power: $\max .132 \mathrm{~kW}$, cooling power: $\max .45 \mathrm{~kW}$, circulation pump: $\max .12 .6 \mathrm{~m}^{3} / \mathrm{h}$ ). The operating range of the test bench 
goes from $-10{ }^{\circ} \mathrm{C}$ to $+90{ }^{\circ} \mathrm{C}$ in order to map operating points of commercially available heat pump systems adequately.

In addition to sophisticated model validation, the test bench is used for determining the location-dependent storage utilization rate depending on borehole depth [5]. By doing so, the influence of groundwater convection on thermal storage process can also be analysed.

\section{Constructive Issues of BHEs}

The analysis of constructive and material-technical issues of BHEs represents another important topic. Here, mechanically, thermally and chemically induced damages on geothermal probes are under investigation. BHE installation mistakes are a frequent cause of mechanical damage. Structural damage in the grout material caused by intensive and rapid frost-thaw cycles is one of the reasons for thermally induced damage. As a possible consequence, undesired annular gaps between grout and probe may form. If a damaged segment of borehole backfilling is located in the depth of aquifers, this is critical with regard to the system tightness, demanded by the authorities. The same is true in case of chemical decompositions of the grout caused by unsuitable materials in corrosive underground conditions. Without the presence of groundwater, the cavities or defects within the grout act as a thermal insulation, which leads to a reduction in the BHE performance. Therefore, the objectives of research are to analyze possible damages caused by means of multiphysical simulations and to derive recommendations for reduction of risk of damage.

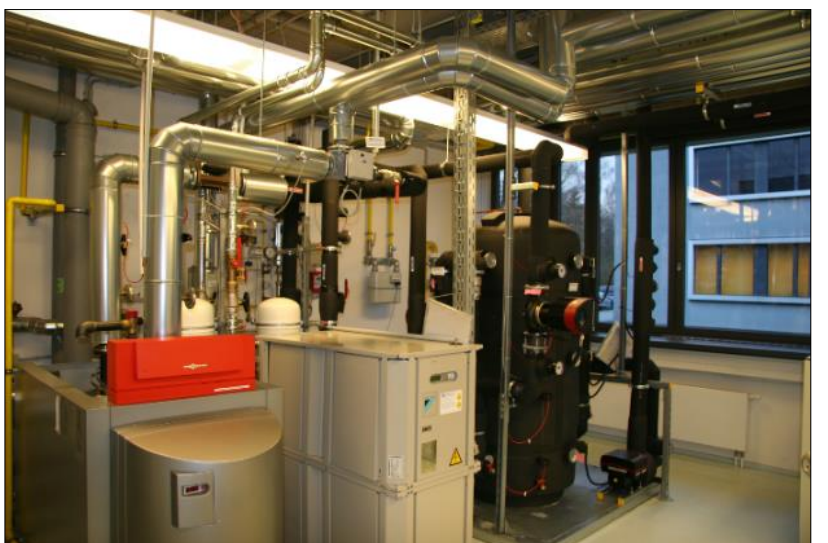

Fig. 1: Test bench (from left to right): gascondensing boiler, compression chiller, thermal storage

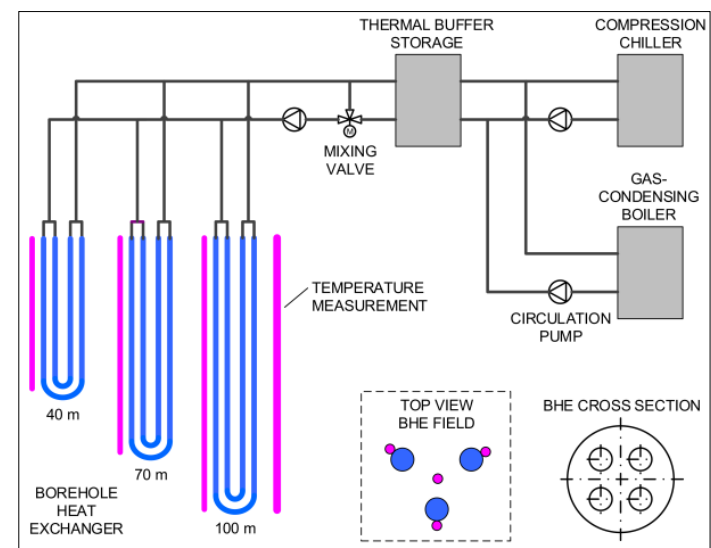

Fig. 2: System scheme

\section{Conclusion}

The junior research group in the ESF-funded research project „Thermal storage process around borehole heat exchanger for heating and cooling of buildings with heat pumps" provides the opportunity to examine the complex topics of near-surface geothermal energy in multidisciplinary manner at Zittau/Görlitz University of Applied Sciences. With reference to the increasing demand of energy supply in buildings using heat pumps, an applicationoriented contribution to the planning practice can be realized.

\section{Acknowledgment}

The European Union and Free State of Saxony fund the described research project. For professional advice, many thanks also go to Prof. Dr. Jens Meinert. 


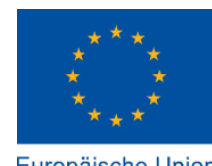

\section{Literature}

[1] BUNDESMINISTERIUM FÜR WIRTSCHAFT UND ENERGIE (2015): Energieeffizienzstrategie Gebäude. Brochure. 146 pp. Berlin.

[2] BAYER, P.; de PALY, M.; BECK, M. (2014): Strategic optimization of borehole heat exchanger field for seasonal geothermal heating and cooling. Applied Energy. Vol. 136, pp. 445-453. DOI: 10.1016/j.apenergy.2014.09.029

[3] KÖLBEL, T. (2010): Grundwassereinfluss auf Erdwärmesonden: Geländeuntersuchungen und Modellrechnungen. Dissertation. 146 pp. Karlsruher Institute of Technology.

[4] BAUER, D. (2011): Zur thermischen Modellierung von Erdwärmesonden und Erdsonden-Wärmespeichern. Dissertation. 121 pp. University of Stuttgart.

[5] KRIMMLING, J. et al. (2015): Speichervorgänge im Umfeld vertikaler Erdsonden von Wärmepumpen. HLH. Vol. 66 (1): 19 pp.

Axel Gerschel; Markus Haack; Prasanth Subramani; Lukas Stöckmann; Thomas Schäfer; Tom Walter; Tino Schütte; Jörn Krimmling 


\section{EFEKTIVNII KONCEPTY NA TOPENÍ A CHLAZENÍ POMOCÍ GEOTERMÁLNÍCH SOND}

Na pozadí stanovení energeticko-politických cílů představují tepelná čerpadla spojená se zemí slibnou technologii na zásobování budov termickou energií. Na odkrytí nevyužívaných potenciálů v povrchní geotermii jsou proto na Vysoké škole Zittau/Görlitz vyvíjeny optimalizační koncepty na zařízení geotermálních sond v kombinovaném topném a chladícím provozu. Hlavni zaměření výzkumu náleží úspoře primární energie, jakož i zlepšení prediktivních modelů pro návrh zařízení, zvláště s ohledem na vliv podzemních vod. Předmětem studie jsou také konstrukční a ekonomické aspekty systémů geotermálních sond.

\section{EFFIZIENTE HEIZ- UND KÜHLKONZEPTE MIT ERDWÄRMESONDEN}

Vor dem Hintergrund energiepolitischer Zielstellungen [1] sind erdgekoppelte Wärmepumpen eine zukunftsfähige Technologie für die thermische Gebäudeenergieversorgung. Zur Erschließung von ungenutzten Potenzialen in der oberflächennahen Geothermie werden daher an der Hochschule Zittau/Görlitz Optimierungskonzepte für Erdwärmesondenanlagen im kombinierten Heiz- und Kühlbetrieb entwickelt. Hierbei steht die Einsparung von Primärenergie ebenso wie die Verbesserung von Vorhersagemodellen zur Anlagenauslegung, insbesondere unter Berücksichtigung von Grundwassereinfluss, im Fokus der Forschung. Untersuchungsgegenstand sind darüber hinaus konstruktive und wirtschaftliche Aspekte von Erdwärmesondenanlagen.

\section{EFEKTYWNE KONCEPCJE OGRZEWANIA I CHŁODZENIA PRZY POMOCY SOND GEOTERMALNYCH}

W odniesieniu do celów określonych w zakresie polityki energetycznej pompy cieplne połączone z ziemią stanowią obiecującą technologię służącą do zasilania budynków energią cieplną. W celu zbadania niewykorzystanego potencjału geotermii powierzchniowej w Szkole Wyższej Zittau/Görlitz opracowywane są koncepcje optymalizujące urządzenia sond geotermalnych pracujących w trybie ogrzewania i chłodzenia. Badania skupiają się głównie na oszczędności energii pierwotnej a także udoskonaleniu modeli prognostycznych w celu zaprojektowania urządzeń, ze szczególnym uwzględnieniem wpływu wód podziemnych. Przedmiotem badań są także aspekty konstrukcyjne i ekonomiczne systemów sond geotermalnych. 